\title{
Taxonomy of Endomychidae Leach (Coleoptera: Cucujoidea) in Korea
}

\author{
Boo Hee Jung*
}

Korean Entomological Institute, Korea University, Seoul, 136-701, Korea

\section{한국산 무당벌레붙이괘딱정벌리목: 머리대장상괘의 분류학적 검토}

\author{
정부희 \\ 고려대학교 한국곤충연구소
}

\begin{abstract}
A taxonomic study of the fungivorous Korean Endomychidae is presented. Ten species in seven genera belonging to three subfamilies are recognized in Korea. Four species, Endomychus gorhami (Lewis), Eumorphus quadriguttatus pulchripes Gerstaecker, Lycoperdina castaneipennis Gorham, and Mycetina ancoriger Gorham, are newly recorded in Korea. Most species are associated with the fungus-grown bark, and mold contaminated materials. I provide information on host-fungi records of Korean Lycoperdina castaneipennis Gorham.
\end{abstract}

Key words: Endomychidae, New record, Taxonomy, Host fungi

초 록: 한국산 무당벌레붙이과(Endomychidae Leach)를 분류학적으로 검토하였다. 한국산 무당벌레붙이과에는 3 아과, 7 속, 10 종이 포함되어 있 는데, 그 중 Endomychus gorhami (Lewis) Eumorphus quadriguttatus pulchripes Gerstaecker, Lycoperdina castaneipennis Gorham, Mycetina ancoriger Gorham 등 4종을 국내에서 처음으로 보고한다. 또한 Lycoperdina castaneipennis의 숙주버섯을 처음으로 보고한다.

검색어: 무당벌레붙이과(Endomychidae), 미기록 4 종, 분류, 숙주버섯

The family Endomychidae comprise around 1,782 species and subspecies in 130 genera of 12 subfamilies worldwide (Shockley et al., 2009). Many endomychid species are represented in all major biogeographical regions, but most are concentrated in the tropical and subtropical regions (Tomaszewska, 2005; Rücker et al.. 2007; Shockley et al., 2009).

The endomychid beetles can be distinguished by the following combination of characters: body broadly oval to elongate, strongly convex to weakly flattened; dorsal surface glossy, smooth and glabrous, or often pubescent; color black to yellow often with contrasting markings; absence of internal antennal vesicle; antennae clavate, forming a loose club; pronotum with longitudinal sulci or sublateral lines (lacking in

*Comesponding author: starrylight12@hanmail.net

Received July 9 2013; Revised September 102013

Accepted October 102013 some Asamorphinae); abdominal ventrite 1 without subcoxal lines; tarsal formula mostly 4-4-4 in both sexes; and fourth tarsomere simple or pseudotrimerous (Tomaszewska, 2000; Skelley and Leshen, 2002).

Endomychids are mostly mycophagous. Both adults and larvae feed largely upon fungi, and are most commonly found under fungus-grown bark, rotten wood, in puffballs, forest litter or debris (Tomaszewska, 2000), and on moldy vegetative material (personal observation). Gut material of Endomychus biguttatus Say, consisted of thick walled hyphae and spores of fungi (Leschen and Carlton, 1988). Also larvae of Lycoperdina have internally feeding the fruiting bodies (puffballs) of the genus Lycoperdon (Lawrence, 1991). Especially Saula japonica Gorham has been reported to have coccinellid-like habits, with both adults and larvae preying on scale insects (Sasaji, 1978).

Only five species were previously recorded from Korea, 
Saula japonica Gorham, Ancylopus pictus asiaticus Strohecker, Lycoperdina mandarinea Gerstäcter, Cymbachus koreanus Chûjô and Lee, Endomychus nigropiceus (Gohram) (Chûjô and Lee, 1993; Kim et al., 1994; Kwon et al., 1996), since Chu (1969) first commented on the distributional records of two species in North Korea.

The purpose of this study is to review the family Endomychidae taxonomically and to provide information of Korean endomychids.

\section{Materials and Methods}

The following records are based on specimens deposited in JUNG's Private Insect Collection (Seoul, Korea) that were mostly collected from fungus-grown bark, puffballs or rotten wood and then partly reared in the laboratory from 2004. Additional records were obtained from specimens contained in the collection of the Sungshin Natural History Museum, Seoul, Korea and Insect Classification Center belonging to the Department of Agricultural Biology, National Academy of Agricultural Science (NAAS), Suwon, Korea. The host fungi were identified based on Breitenbach and Kränzlin (1986) and Lee (1988).

The abbreviations used in this study are as follows: GW (Gangwon-do), SL (Seoul), GG (Gyeonggi-do), GB (Gyeongsangbuk-do), GN (Gyeongsangnam-do), JN (Jeollanamdo), JJ (Jeju-do); Mt. (Mountain).

\section{Systematic Account}

\author{
Endomychidae Leach, 1815 무당벌레붙이과 \\ Endomychides Leach, 1815: 116. \\ Fungicolae Latreille, 1825: 406. \\ Endomychidae Stephens, 1831: 398. \\ Endomycites Newman, 1834: 420. \\ Lycoperdinae Redtenbacher, 1844: 117. \\ Sulcicolles Mulsant, 1846: 1. \\ Endomychidea Costa, 1850: 1 . \\ Endomycici Gorham, 1873a: 1. \\ Endomychoidea Verhoeff, 1895: 272.
}

Key to the Korean subfamilies of Endomychidae (modified from Tomaszewska, 2000)

1. Head with occipital file; anterior margin of the pronotum usually with stridulatory membrane …... Lycoperdininae

- Head without occipital file, (sometimes with fine microsculpture); anterior margin of the pronotum without stridulatory membrane

2. Body covered with dense and usually long setae; prementum of labium transverse, at most weakly longer than mentum Stenotarsinae

- Body glabrous or with minute setae; prementum of labium longer than wide, at least twice longer than mentum ........ Endomychinae

Subfamily Endomychinae Gerstaecker, 1857 무당벌레붙이 아과(신칭)

Endomychini Gerstaecker, 1857: 239.

Endomychina Thomson, 1863: 300.

Endomycidae Gorham, 1873a: 28.

Endomychites Chapuis, 1876: 130.

\section{Endomychus Panzer, 1795}

Endomychus Panzer, 1795: 175.

Cyanauges Gorham [in Gorham and Lewis], 1874a: 54.

Caenomychus Lewis, 1893: 153.

\section{Key to the Korean species of Endomychus}

1. Body with fine and regular punctures; color bluish black, without black or yellow spots on elytra; abdomen bluish black E. gorhami

- Body with large and coarse punctures; color bluish black, often with black or yellow spots; abdomen yellow

E. nigropiceus

Endomychus gorhami (Lewis) [in Gorham and Lewis], 1874 남색무당벌레붙이(신칭) (Figs. 1, 9, 15)

Cyanauges gorhami Lewis [in Gorham and Lewis], 1874a: 55.

Caenomychus gorhami: Mader, 1936: 100.

Caenomychus violaceipennis Mader, 1941: 170.

Endomychus gorhami kyushuensis Sasaji, 1978: 25. 


\section{Redescription}

Body 3.6-5.0 mm in length; body bluish black, ovate, convex, glabrous, glossy; with fine and regular punctures. Head weakly transverse, slightly narrowing from eyes towards labrum; eyes prominent, coarsely faceted; antennal grooves absent; antennomeres 9-11 widened, forming loose and weakly flattened club; apical antennomere almost quadrate, obliquely rounded; frontoclypeal ridge almost straight; clypeus transverse
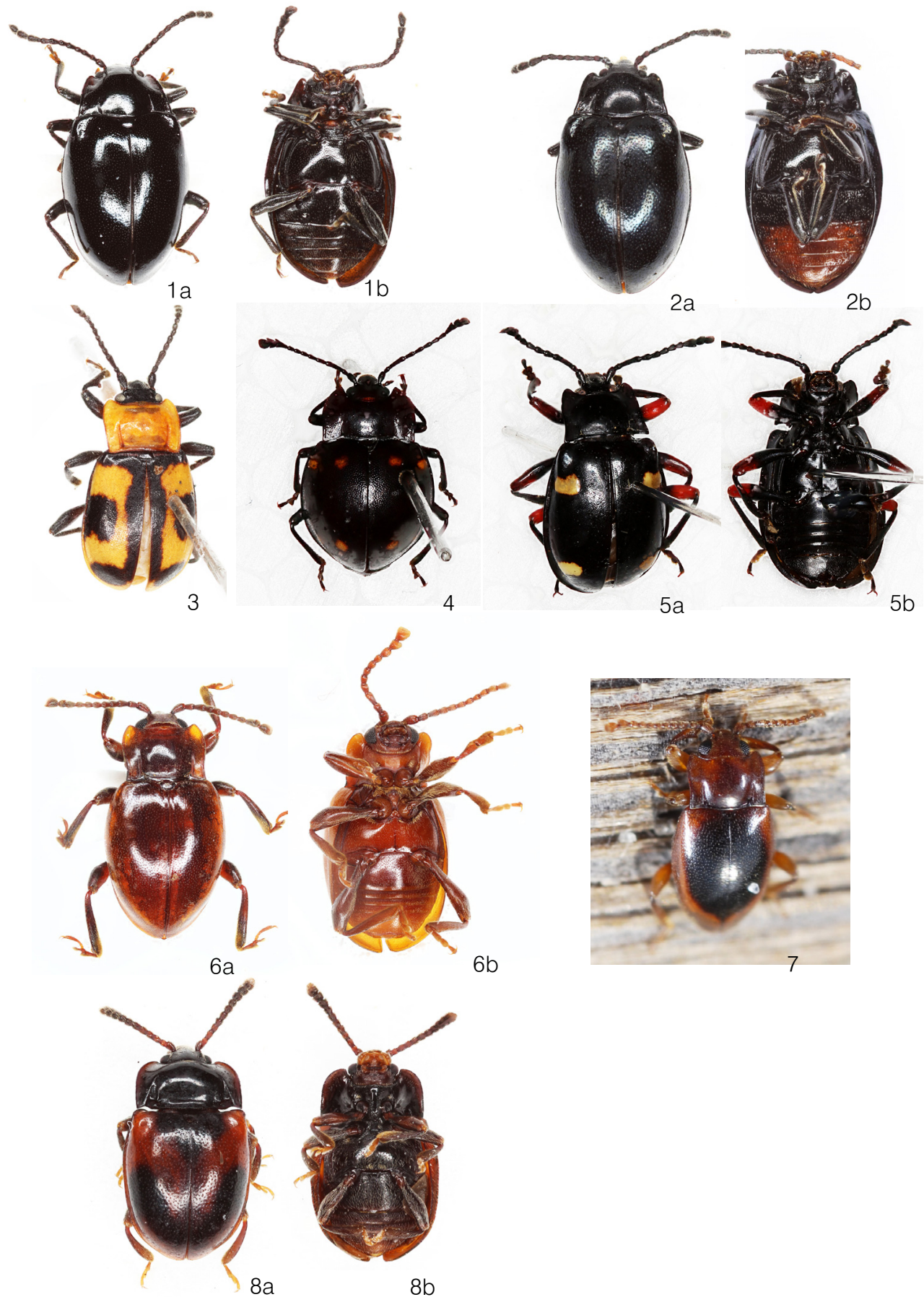

Figs. 1-8. Habitus of Endmychidae (a, dorsal; b, ventral). 1. Endomychus gorhami; 2. Endomychus nigropiceus; 3. Ancylopus pictus asiaticus; 4. Cymbachus koreanus; 5. Eumorphus quadriguttatus pulchripes; 6. Lycoperdina castaneipennis; 7. Lycoperdina mandarinea (nature photo); 8. Mycetina ancoriger. 
and flat, truncate at apex; apical maxillary palpomere securiform; apical labial palpomere cylindrical, narrowing to apex. Pronotum transverse, weakly convex; all margins distinctly rimmed; anterior margin arched; anterior angles strongly produced anteriad and distinctly rounded; lateral margins almost parallel-sided; basal margin sinuous, with distinct transverse basal sulcus at near basal margin, with longitudinal and deep sulci at subbasal part; posterior angles acutely produced. Prosternal process moderately broad, distinctly separates front coxae and almost extends posteriad beyond coxae. Elytra oval-elongate, with fine and distinct punctures, strongly convex; epipleuron incomplete apically. Leg. procoxae circular; trochanterfemoral attachment oblique; femur twice as wide as tibia; tibia without apical spurs; tarsomeres 1 and 2 flattened and ventrally lobed; tarsomere 3 very small, three times shorter than 2 and four times shorter than tarsmomere 4 (tarsi pseudotrimerous); claws simple; empodium very small and bisetose. Mesoventrite with a pair of pits near anterior margin, separately by intercoxal process; intercoxal process almost square, slightly transverse, flat; mesotrochantin exposed; metaventrite simple, large, very transverse.

Specimens examined. [GW] $10 \% 110^{\top}$ Seonja-ryeong, Yongpyeong-gun, Gangwon-do, 11.vi.2012, B.-H. Jung, under the bark attaching Schizophyllum commune.

Distribution. Korea (new record), China, Japan.

\section{Endomychus nigropiceus (Gorham, 1887) 검무당벌레붙이}

(Fig. 2)

Cyanauges nigropiceus Gorham, 1887: 651.

Caenomychus nigropiceus: Ohta, 1931: 234.

Endomychus hiranoi Sasaji, 1978: 27.

Endomychus nigropiceus: Chûjô and Lee, 1993: 98; Kwon et al., 1996: 159.

\section{Redescription}

Body 3.8-4.7 mm in length; body bluish black, often with black or yellow spots; ovate, convex, glabrous; with large and coarse punctures; abdomen yellow. Head weakly transverse; eyes prominent, coarsely faceted; antennal grooves absent; antennomeres 9-11 widened, forming loose and weakly flattened club; apical antennomere oblong; apical maxillary palpomere securiform; apical labial palpomere elongate.
Pronotum transverse, most widest at base, convex; with coarse punctures; all margins rimmed; anterior margin strongly sinuous; lateral margins almost parallel-sided, slightly narrowed anteriad; basal margin sinuous, with distinct transverse basal sulcus at near basal margin, with longitudinal and deep sulci at subbasal part. Prosternal process moderately broad, distinctly separates front coxae and extends posteriad beyond coxae. Elytra oval-elongate, covered with very short hair; with coarse, large punctures and rugose; strongly convex. Leg. procoxae circular; femur twice as wide as tibia; tibia without apical spurs; tarsi pseudotrimerous. Msoventrite with a pair of pits near anterior margin; intercoxal process almost square to slightly transverse and flat; mesocoxa circular, trochantin exposed.

Specimens examined. [JJ] 2 ㅇ Seongpanak, Mt. Halla, Jeju-si, 16.viii.2012, B.-H. Jung, under the mycelia.

Distribution. Korea, Japan.

\author{
Subfamily Lycopendinae Redtenbacher 방귀무당벌레붙이 \\ 아과(신칭) \\ Lycoperdinae Redtenbacher, 1844: 118. \\ Eumorphidae Gistel, 1856: 382. \\ Eumorphini Gerstaecker, 1857: 214. \\ Dapsini Gerstaecker, 1858: 170. \\ Corynomalidae Gorham, 1873a: 14. \\ Amphicini Csiki, 1910: 25. \\ Beccariini Arrow, 1925: 278. \\ Amphisternini Strohecker, 1964: 320.
}

Key to the Korean genera of subfamily Lycoperdinae (modified from Tomaszewska, 2005)

1. Body more broadly oval, strongly convex

Cymbachus Gerstaecker

- Body long-oval, moderately or weakly convex ………... 2

2. Elytra always with markings ….................................... 3

- Elytra always without markings …………………........ 4

3. Body elongate, mandible at most narrowly chisel-shaped at apex; elytra almost always with four yellow spots .....

Eumorphus Weber

- Body long-oval; mandible long and sharp at apex; elytra almost always with black spots ………. Ancylopus Costa 

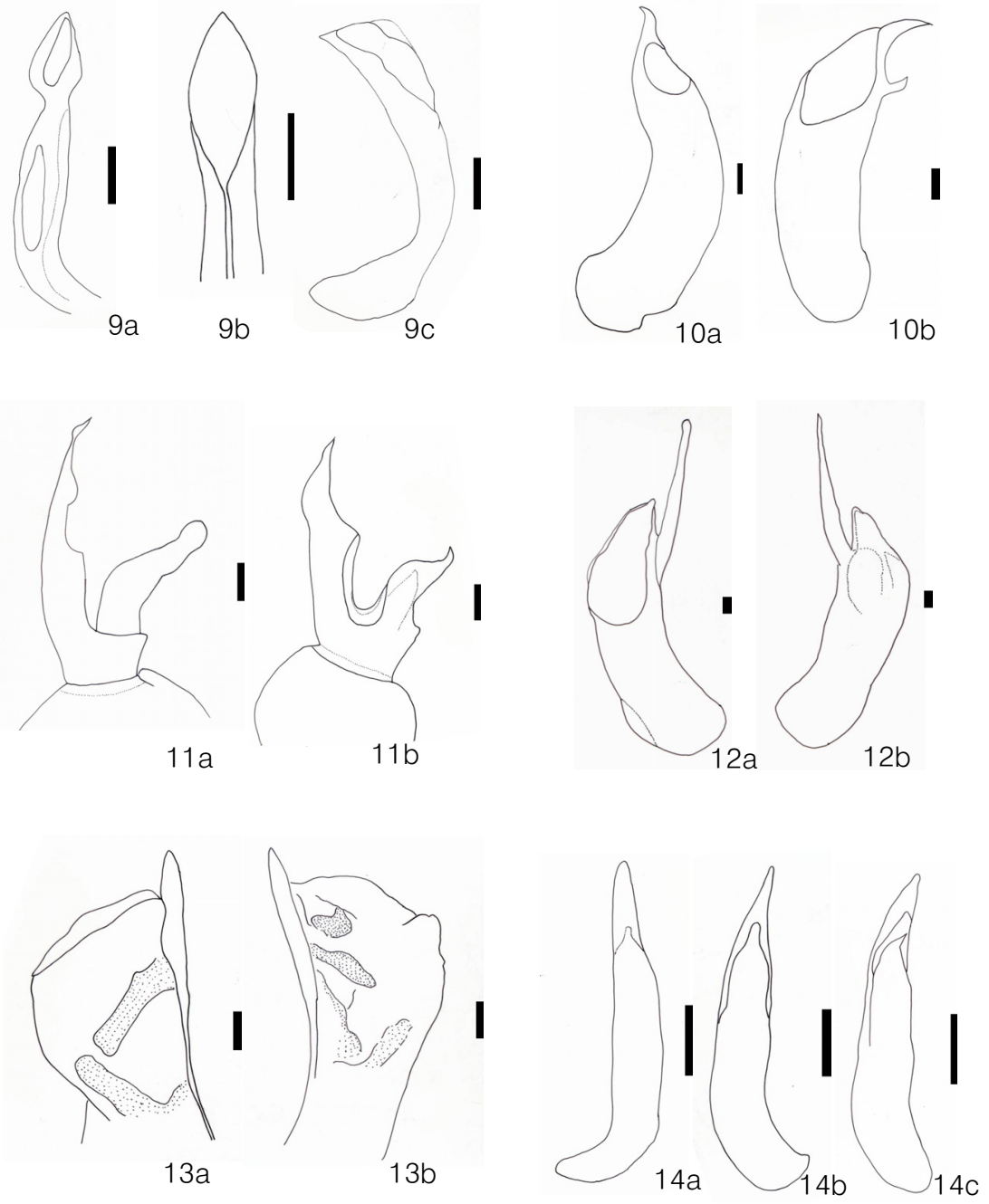

Figs. 9-14. Genitalia of Endmychidae (Each scale bar $=0.1 \mathrm{~mm}$ ). 9. Endomychus gorhami (a. dorsolateral; b. ventral; c. dorsal); 10. Ancylopus pictus asiaticus (a, dorsal; $\mathrm{b}$, dorsolateral); 11. Cymbachus koreanus (a. dorsal; b. dorsovental); 12. Eumorphus quadriguttatus pulchripes (a. lateroventral; b. dorsovental); 13. Lycoperdina castaneipennis (a. lateral, left; b. lateral, right); 14. Mycetina ancoriger (a. dorsal; b. ventral; c. lateroventral).

4. Antennomeres 10 and 11 clubbed; prosternal process strongly reduced; procoxae contiguous; prosternum narrow, not prolonged behind Lycoperdina Latreille

- Antennomeres 9 and 11 clubbed; prosternal process long and narrow; procoxae well separated; prosternum broader, prolonged behind

Mycetina Mulsant

\section{Ancylopus Costa, 1850 무당벌레붙이속(신칭)}

Ancylopus Costa, 1850: 13.

Ancylopus pictus asiaticus Strohecker, 1972 무당벌레붙이

(Figs. 3, 10, 16)

Ancylopus pictus asiaticus Strohecker, 1972: 706; Kim,
1983: 159; Kim and Yoo, 1987: 213; Kim et al, 1994: 169; Kwon et al., 1996: 159; Kim and Kim, 1996: 43; Kim et al., 1999: 162; Kim, 2000: 127; Rücker et al., 2007: 562.

\section{Redescription}

Body 4.5-5.0 mm in length; body mostly black, pronotum yellow, elytron with two large yellow markings; elongate and glossy; head and pronotum weakly convex, elytra strongly convex; covered with very short pubescence; mixed with fine and large punctures and rugose. Head partially retracted in prothorax; eyes prominent, very coarsely faceted; occiput with cephalic stridulatory area (occipital file); apical 2 antennomeres 
wide and depressed and forming loose club; apical antennomere oval; apical maxillary palpomere cylindrical, rounded at apex; apical labial palpomere ovate. Pronotum almost quadrate, transverse, weakly convex; with crown shape sulcus; with tiny, sparse and irregular puncture; anterior margin sinuate, with stridulatory membrane at front area; anterior angles gently projected and round, lateral margins almost parallel-sided; basal margin straight, with transverse two sulcus at basal and subbasal margin; middle and subbasal part with deep and longitudinal lateral sulci; with two foveae at subbasal part; basal angles acute. Prosternum with a pair of pits at the front of procoxal cavity; prosternal process very narrow, thin and short, extending to coxae; front coxa prominent and contiguous. Elytra oblong, strongly convex, with coarse, dense irregular punctures; between punctures weakly rugose; mostly black, with two large yellow markings. Leg. procoxae circular; femur widest at apical $1 / 3$ part, strongly setose; tibia and tarsus with dense setose than femur; tibia widening apically, without apical spurs; tarsi pseudotrimerous. Mesoventrite with a pair of pits near anterior margin; intercoxal process short, not extends beyond mosocoxae; mesotrochantin exposed; Metaventrite transverse, with moderately longitudinal median line.

Sexual characteristics. male: front tibiae with tubercle at apical 1/2 part inner side; middle tibiae with tubercle at apical 1/3 part inner side. female: front and middle tibiae simple, without tubercles.

Specimens examined. [SL] $1 \sigma^{\top}$ Mt. Cheonggye, Wonji-dong, Seocho-gu, 20.ii.1999, T.-W. Kim; $10^{\top}$ Hangang riverside, Pungnap-dong, Songpa-gu, 14.vii.2004, J.-B. Seung; $20^{7}$ Olympic park, Bangi-dong, Songpa-gu, 10.v.2005, B.-H. Jung; [GG] 1 ㅇ Baengnyeong island, Ongjin-gun, 31.viii.1987, H.-J. Yoo; $10^{x}$ Cheonggyesa, Uiwang-si, 19.v.1989, H.-N. Shim; 1 오, Daean-ri, Hyondeok-myeon, Pyeongtaek-si, 2.viii,1996, T.-M. Han; [GB] $20^{\top}$ Mt. Seondal, Buseok-myeon, Namdae-ri, Yeongju-si, 29.vi.1998, J.-I.; [JN] 1 \& Jaeon island, Sinan-gun, 16.viii.2000, B.-H. Jung.

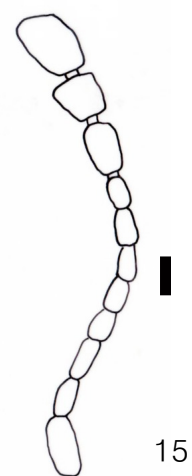

15

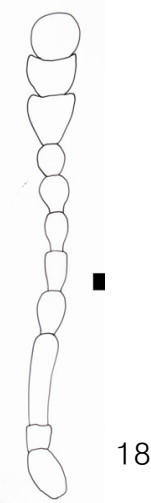

18
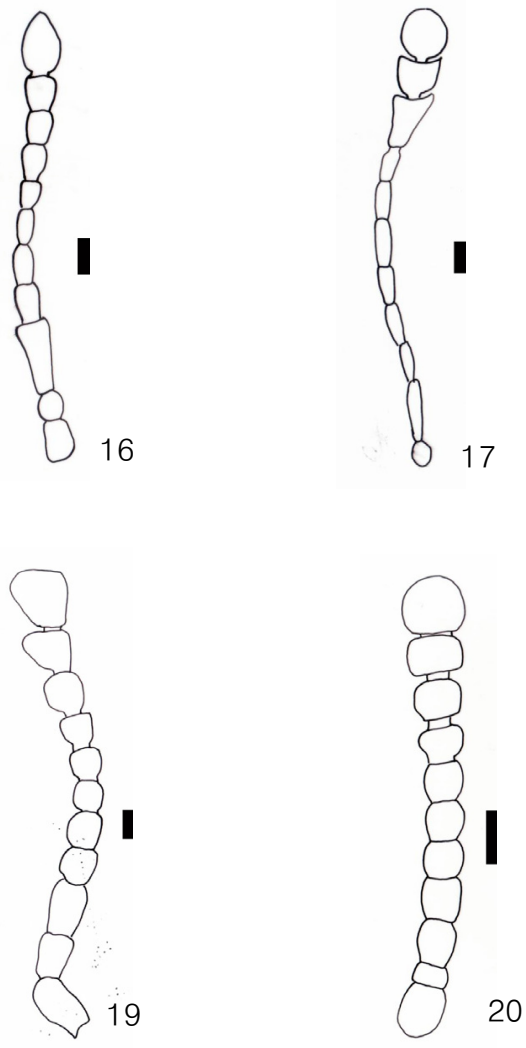

Figs. 15-20. Antenna of Endmychidae (scale bar $=0.1 \mathrm{~mm}$ ): 15. Endomychus gorhami; 16. Ancylopus pictus asiaticus; 17. Cymbachus koreanus; 18. Eumorphus quadriguttatus pulchripes, 19. Lycoperdina castaneipennis; 20. Mycetina ancoriger. 
Distribution. Korea, Japan, China, Taiwan, Vietnam, India.

Remarks. Ancylopus pictus asiaticus is the most common species in Korea.

\section{Cymbachus Gerstaecker, 1857 우리무당벌레붙이속 \\ Cymbachus Gerstaecker, 1857: 233.}

\section{Cymbachus koreanus Chûjô and Lee, 1993 우리무당벌레붙} 이(Figs. 4, 11, 17)

Cymbachus koreanus Chûjô and Lee, 1993: 95; Kwon et al., 1996: 159; Kim, 2002: 263; Rücker et al., 2007: 562.

\section{Redescription}

Body 7.5-7.9 mm in length; body black to dark umber; pronotum weakly convex, elytra strongly convex; antennae and tibia slender and long; elytra each with four yellow small markings. Head sparsely punctate; eyes prominent, very finely faceted; apical 3 antennomeres depressed and wide, forming loose club; apical antennomere oblong; apical maxillary palpomere cylindrical, tapering apically and oblique at apex; apical labial palpomere triangular. Pronotum weakly convex, sparsely and strongly punctate; anterior margin deeply sinuate, with prominent stridulatory membrane in front part; anterior angle strongly produced, lateral margins almost parallel-sided, roundly narrowed anteriad; basal margin sinuate, transverse basal sulcus close to basal margin, with two foveae subbasal parts; basal angle acute. Prostenal process narrow and short, V-shaped at apex, not project beyond coxa. Elytra strongly convex, with strong and dense punctures, strongly rugose; eytral epipleuron very wide at basal part, and strongly narrowed apically; each elytra with four yellow patches. front spots placed on subbasal and hind one placed on subapical part. Leg. tibiae slender, gradually thickened apically; tarsi pseudotrimerous. Intercoxal process of metaventrite wide and shrot, reach to coxa; metaventrite transverse, with longitudinal and medial line.

Sexual characteristics. male: middle tibiae with short tubercle at subapical part inner side. female: middle tibiae simple.

Specimens examined. [GG] $10^{\pi}$ Anyang-si, 27.vi.1992, DJK; $10^{\top}$ Gwanggyo, 15.viii.1996, LJS; [JB] 1 Mt. Deokyu,

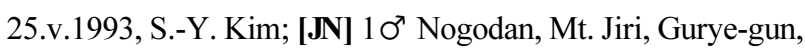

2.viii.1996, G.-J. Gang; 1 \& Piagol, Mt. Jiri, Gurye-gun, 29.vii.1997, S.-Y. Son; $10^{7}$ ditto, 22.v.1999, S.-W. Park; [GN] 1 오. Mt. Jiri, Sancheong-gun, 27.vi.1993, H.-Y. Kim.

Distribution. South Korea (endemic).

\author{
Eumorphus Weber, 1801 점무늬무당벌레붙이속(신칭) \\ Eumorphus Weber, 1801: 31. \\ Eumorphoides Guérin-Méneville, 1858: 12. \\ Enaisimus Guérin-Méneville, 1858: 16. \\ Haplomorphus Guérin-Méneville, 1858: 18. \\ Heterandrus Guérin-Méneville, 1858: 26.
}

\section{Eumorphus quadriguttatus pulchripes Gerstaecker, 1857 네 점무늬무당벌레붙이(신칭) (Figs. 5, 12, 18) \\ Eumorphus quadriguttatus pulchripes Gerstaecker, 1857: 228.}

\section{Redescription}

Body 10-12 mm in length; body mostly black; elongate and glossy; head and pronotum weakly convex, elytra strongly convex; covered with very short pubescence; mixed with fine and large punctures and rugose; elytra with four yellow patches (markings), femoral 1/2 part red. Head partially retracted in prothorax; eyes prominent, very coarsely faceted; occiput with cephalic stridulatory area (occipital file); apical antennomeres 3 strongly widened, forming loose club, apical antennomere almost quadrate; apical maxillary palpomere cylindrical, narrowing at apex; apical labial palpomere ovate. Pronotum almost quadrate, parallel-sided weakly convex; with tiny, sparse and irregular puncture; anterior margin strongly arched, with stridulatory membrane at front area; anterior angles strongly produced, lateral margins almost parallel-sided; basal margin straight, transverse basal sulcus close to basal margin, subbasal part with deep and longitudinal lateral sulci; with two foveae at subbasal part; posterior angles acute. Prosternum with a pair of pits at the front of procoxal cavity; prosternal process narrow and long, extend out procoxae. Elytra oblong, strongly convex, with coarse, dense irregular punctures; between punctures weakly rugose; elytra with 2 yellow spots, front spot touching or almost near lateral margin; subapical spot almost near lateral margin; eytral epipleuron narrowing and vanishing at apex. Leg. front coxa prominent and circular; femora partly orange or red; femur swollen, red at apical 1/2 part, widest at 
apical 3/4 part, about twice than width of tibia; tibia gradually widening apically; tarsi pseudotrimerous; claws simple. Mesoventrite with longitudinal sulcus medially and with a pair of pits near anterior margin; intercoxal process short and wide, not extends beyond mesocoxae; meso-trochantin exposed; metaventrite transverse, with moderately longitudinal median line.

Sexual characteristics. male: Front tibia with short and minute proximal tooth at apical $1 / 4$ part; middle tibiae with small tubercles surmounted by tuft setae at apical 1/4 part inner side; sternites 3-5 with tufts of golden setae, most conspicuous on 4. female. front and middle tibia simple without tooth; sternites 3-5 without tufts of golden setae.

Specimen examined. [SL] $10^{\pi}$ Doseonsa, Mt. Bukhan, Dobong-gu, 22.vii.2006, B.-H. Jung, under the mycelia; [GG] $40^{\top} 10$ ㅇ Yuldong Park, Bundang-gu, Seongnam-si, 5.vi.2013, B.-H. Jung and J.-Y. Park, under the mycelia.

Distribution. Korea (new record), Japan, China, Taiwan, Nepal, Sri Lanka, India.

Remarks. This species mostly feeds on mould associated with decaying trees of Quercus which smitten by the oak wilt disease by Raffaelea quercus-mongolicae.

\section{Lycoperdina Latreille, 1807 방귀무당벌레붙이속(신칭)}

Lycoperdina Latreille, 1807: 73.

Golgia Mulsant, 1846: 17 (as subgenus).

Lycoperdinella Arrow, 1920: 23 (Homonym).

Lycoperdinodes Arrow, 1923: 485 (Replacement name for Lycoperdinella Arrow).

Falsoylaia Pic, 1945: 10.

\section{Lycoperdina castaneipennis Gorham, 1874 방귀무당벌레붙} 이(신칭) (Figs. 6, 13, 19)

Lycoperdina castaneipennis Gorham, 1874b: 151.

\section{Redescription}

Body 4.8-6.0 mm in length; body brownish red to light brownish black; ovate and glossy; head and pronotum weakly convex, elytra strongly convex; covered with fine and very short pubescence; with fine puncture. Head partially retracted in prothorax; eyes prominent, very coarsely faceted; occiput with cephalic stridulatory area; antennal grooves absent; apical antennomeres 2 wide, forming loose club; apical antennomere almost quadrate; apical maxillary palpomere cylindrical, rounded at apex; apical labial palpomere ovate. Pronotum almost quadrate, transverse, weakly convex; with fine puncture; all margins rimmed; anterior margin sinuate, with stridulatory membrane; anterior angles strongly projected; basal sulcus distinct, lateral sulci deep and long; with two foveae at subbasal part; basal angles acute. Prosternum with a pair of pits at the front of procoxal cavity; prosternal process very thin and short; front coxa prominent and contiguous. Elytra oval-elongate, strongly convex, with fine and irregular punctures. Leg. procoxae circular; femur widest at apical $1 / 3$ part, about twice than width of tibia; tibia widening apically; tarsi pseudotrimerous. Mesoventrite with a pair of pits near anterior margin; intercoxal process short and narrow, not extends beyond mosocoxae; meso-trochantin exposed; metaventrite transverse, with longitudinal line.

Sexual characteristics. male: front and middle tibiae with tubercles inner side. female: front and middle tibiae without tubercles inner side.

Specimens examined. [GW] $10 \% 110^{\top}$ Daegwallryeong, Yongpyeong-gun, Gangwon-do, 10.x.2011, H.-G. An ex Lycoperdon pyriforme; [SL] $10^{7}$ Gildong Natural Ecological Park, Gil-dong, Gangdong-gu, 23.x.2004, B.-H. Jung ex Lycoperdon pyriforme; [GG] 3 ㅇ $40^{\top}$ Dongguneung, Guri-si, 9.vii.2009 ex Lycoperdon perlatum B.-H. Jung.

Distribution. Korea (new record), Japan.

Biological notes. Lycoperdina castaneipennis Gorham is the mycetobiont which is obligatory fungal inhabitants. This species inhabit in the fruiting bodies of Lycoperdon (e.g. Lycoperdon pyriforme, L. perlatum),

\section{Lycoperdina koltzei Reitter, 1887}

Lycoperdina koltzei Reitter, 1887: 508; Rücker et al., 2007: 565 .

Distribution. Korea, Mongolia, Russia (Far East).

Remarks. No Korean specimens of this species were available. Rücker et al., (2007). documented this species in their catalog, but no Korean record in the recent Korea, Japan, China and Russa (Far East) insect list. 
Lycoperdina mandarinea Gerstaecker, 1858 꼬마무당벌레 붙이(Fig. 7)

Lycoperdina mandarinea Gerstaecker, 1858: 212; Kim et al., 1994; 170; Kwon et al., 1996: 159; Rücker et al., 2007: 565.

Distribution. Korea, Japan, China, Russia (Far East), Mongolia, Taiwan, Cambodia, Laos, Vietnam.

Remarks. They fed on Myxomycota associated with decaying plants. I collected two specimens of this species in Jaeun island (Sinan-gun, Jeollanamdo: 28.iv.2010), but they were unfortunately lost. Only a photograph is provided.

\section{Mycetina Mulsant, 1846}

Mycetina Mulsant, 1846: 15.

Mycetinina Pic, 1929: 35 (as subgenus).

Phaeomychus Gorham, 1887: 649.

\section{Mycetina ancoriger Gorham, 1873 네모무당벌레붙이(신칭)}

(Figs. 8, 14, 20)

Mycetina ancoriger Gorham, 1873b: 206.

\section{Redescription}

Body 2.4-3.4 mm in length; body mostly black, elongate, glabrous and glossy; head weakly convex, pronotum and elytra strongly convex; mixed with fine and large punctures and weakly rugose; elytron with red markings; antennae, legs, mouthpart, ventral part reddish brown. Head black; eyes prominent, very coarsely faceted; occiput with cephalic stridulatory area; short, extend beyond pronotum; moniliform, from antennomere 9 to 11 gradually widened apically, forming weak loose club, apical antennomere oval; apical maxillary palpomere cylindrical, rounded at apex; apical labial palpomere ovate. Pronotum transverse, parallel-sided; strongly convex; with tiny, sparse and irregular puncture; anterior margin very weakly arched, with stridulatory membrane at front area; lateral margins almost parallel-sided; basal margin straight, weakly sinuous at subbasal part, transverse basal sulcus close to basal margin, deep and oblique lateral sulci at subbasal parts; with two foveae at subbasal part. Prosternum with a pair of pits at the front of procoxal cavity; prosternal process wide and very long, extend out procoxae. Elytra oblong, strongly convex, with coarse, regular punctures; between punctures weakly reticulate; elytra with red marking. Leg. Front coxa prominently separate; covered with dense, whitish seta; femur strongly swollen, widest at apical 3/4 part, about twice than width of tibia; tibia gradually widening apically; tarsi pseudotrimerous. Mesoventrite covered with decumbent whitish seta and with a pair of pits near anterior margin; intercoxal process short and wide, not extends beyond mosocoxae; mesotrochantin exposed.

Specimens examined. [GW] 2exs Mt. Hambaik, Gohan-eup, Geongseon-gun, 14.viii.1999, T.-W. Kim; [GB] $10^{\text {T}}$ Mt. Unmun, Unmun-myeon, Cheongdo-gun, 5.v.2011, B.-H. Jung.

Distribution. Korea (new record), Japan.

Remarks. This species was the endemic species in Japan (Rücker et al., 2007) but collected in Korea. Japanese species occurs variation on elytral spots.

\author{
Subfamily Stenotarsinae Chapuis, 1876 노랑무당벌레붙이 \\ 아과(신칭) \\ Stenotarsites Chapuis, 1876: 125. \\ Dapsini (in part) Gerstaecker, 1858: 170. \\ Paleomorphidae Gorham, 1873a: 24. \\ Stenotarsini Csiki, 1901: 37.
}

Saula Gerstaecker, 1858 노랑무당벌레붙이속(신칭)

Saula Gerstaecker, 1858: 223.

Aediarthromorpha Pic, 1922: 239.

\section{Saula japonica Gorham, 1874 노랑무당벌레붙이}

Saula japonica Gorham, 1874b: 224; Chu, 1969: 118; Kim et al., 1994: 169; Kwon et al., 1996: 159.

Distribution. Korea, Japan, Taiwan.

Remarks. No Korean specimens of this species were available. This species has been cited literally in Korean insect list, since Chu(1969) reported firstly in the North Korean insect list. However Rücker et al., (2007) documented that this species was not distributed in Korea (only distributed in Japan and Taiwan) in their catalog.

Taxonomic study of Endomychidae (Coleoptera) in Korea 


\section{Acknowledgement}

I'm very grateful to Dr. Hae-Chul Park (Insect Classification Center of NAAS, Suwon) and Ah-Young Kim(Sungshin Nature History Museum, Seoul) for providing some specimens available for this study. This study was carried out through "The Survey of Korean Indigenous Species" supported by National Institute of Biological Resources (NIBR) of Ministry of Environment of Korea.

\section{Literature Cited}

Arrow, G.J., 1920. A list of the endomychid Coleoptera of Indo-China, with descriptions of new species. Ann. Mag. Nat. Hist., 9: 321-336.

Arrow, G.J., 1923. Notes on endomychid Coleoptera and descriptions of new species in the British Museum. Trans. Ent. Soc. Lond., 484-500

Arrow, G.J., 1925. Coleoptera. Clavicornia. Erotylidae, Languriidae, and Endomychidae. pp. 268-405. In: Arrow, G.J. (Ed.), The Fauna of British India, including Ceylon and Burma. Taylor and Francis, London.

Breitenbach, J. and Kränzlin, F., 1986. Fungi of Switzerland, Volume 2: Non gilled fungi(Heterobasidiomycetes, Aphyllophorales, Gastromycetes). Verlag Mykologia, Switzerland.

Chapuis, F., 1876. Famille des erotyliens, des endomychides et des coccinellides. In: Lacordaire, T. and Chapuis, F. (Eds), Histoire naturelle des insectes. Genera des Coléoptères ou exposé méthodique et critique de tous les genres proposés jusqu'ici dans cet ordre d'insectes. Tome 12. Roret, Paris. 424 p.

Chu, D.R., 1969. Checklist of insect classification. Gwahakweon Publishing, Pyeongyang.

Csiki, E., 1901. Catalogus Endomychidarum. Term. Fuze., 24: 2-53.

Csiki, E., 1910. Pars 12: Fam. Endomychidae. pp. 1-68. In: Schenkling, S. (Ed.), Coleopterorum Catalogus. W. Junk, Berlin.

Chûjô, M.T., and Lee, C.E., 1993. Endomychidae from Korea (Insecta, Coleoptera). Esakia, 33: 95-98.

Gerstaecker, A, 1857. Versuch einer systematischen Auseinandersetzung der Gattungen Eumorphus Web. und Endomychus Payk. Arch. Natur., 23: 211-243.

Gerstaecker, A., 1858. Monographie der Endomychidae, einer Familie der Coleopteren. XIV + 433 p., 3 pls. In: Gerstaecker, A. (Ed.), Entomographien. Abhandlungen in Bereich der Gliederthiere, mit besonderer Benutzung der Koenigl. Entomologischen Sammlung zu Berlin. W. Engelmann, Leipzig.

Gistel, J.N.F.X., 1856. Die Mysterien der europäischen Insectenwelt. Ein geheimer Schlüssel für Sammler aller Insecten-Ordnungen und Stände, behufs des Fangs, des Aufenhalts-Orst, der Wohnung, Tag-und Jahreszeit u. s. w., oder autoptische Darstellung des Insectenstaats in seinem Zusammenhange zum Bestehen des Naturhaushaltes überhaupt und insbesondere in seinem Einflusse auf die phanerogamische und cryptogamische Pflanzenberötzerrung Europa's. Zum ersten Male nach 25jährigen eigenen Erfahrungen zusammengestellt und herausgegeben. Tobias Dannheimer, Kempten. 530 p.

Gorham, H.S., 1873a. A Catalogue of the Coleopterous group, Endomycici, with descriptions of new species, and notes. Williams and Norgate, London. $64 \mathrm{p}$.

Gorham, H.S., 1873b. A list of Endomychidae collected in Japan by Geo. Lewis, Esq. with descriptions of new genera and species. Ent. Mon. Mag., 9: 205-207.

Gorham, H.S., 1874a. [new taxa]. In: Gorham, H.S. and Lewis, G.: Description of a new genus and species of Coleoptera from Japan. Ent. Mon. Mag., 11: 54-55.

Gorham. H.S., 1874b. Descriptions of new species of Coleoptera from Japan. Ent. Mon. Mag., 10: 224-226.

Gorham, H.S., 1887. Revision of the Japanese species of the coleopterous family Endomychidae. Pro. Gen. Meet. Sci. Bus. Zool. Soc. Lond., 642-653.

Guérin-Méneville, F.E., 1858. Matériaux pour une Monographie des Coléoptères du groupe des Eumorphides, et plus. spécialement du genre Eumorphus. Rev. Mag. Zool. Pur. Appl., (2)10: 10-29.

Kim, J.I., 1983. Fauna of Coleoptera from the islands in Jodo-myon, Junlanam-do province. Rep. Sur. Nat. Env. Kor., 3: 159-176.

Kim, J.I., 2000. Coleopteran fauna of the natural forest reserve area of Uljin-gun, Gyeoungsangbuk-do. Rep. Kor. Asso. Conser. Nat.., 40: 127-147.

Kim, J.I., 2002. The Korean endemic species of Coleoptera (Insecta). Jour. Kor. Bio., 7: 263-293.

Kim, J.I. and Yoo, H.J., 1987. Summer seasonal fauna of the insect from the Island Paengnyong-do of the province Kyonggi-do, Korea. Rep. Sur. Nat. Env. Kor., 7: 213-235.

Kim, J.I., Kwon, Y.J., Paik, J.C., Lee, S.M., Ahn, S.L., Park, H.C., Chu, H.Y., 1994. Order 23. Coleoptera. Pp.117-214. In: The Entomological Society of Korea and Korean Society of Applied Entomology (Eds.) Check List of Insects from Korea. Kon-Kuk University Press, Seoul.

Kim, J.I. and Kim, J.K., 1996. On the insect fauna of Mt. Daiam and Dutayeon-Coleoptera, Hymenoptera, Diptera. Nat. Con, 94: 43-51.

Kim, J.I., Kim, S.Y., Lee, H.A., Han, T.M. and Kang, T.H., 1999. Coleopteran fauna from Mts. Seondal and Eorae. Rep. Kor. Asso. Conser. Nat., 39: 125-134.

Kwon, Y.J., Lee, J.H., Seo, D.J., Ahn, S.L., Heo, E.Y. and Yeo, Y.S., 1996. Literature survey on biodiversity in Korea. Kor. Nat. Coun. Conser. Nat., pp. 162-163.

Latreille, P.A., 1807. Genera crustaceorum et insectorum secundum 
ordinem naturalem in familia disposita, iconobis exemplisque plurimis explicta. Tomus tertius. Amand Koenig, Parisii et Argentorati. $258 \mathrm{p}$.

Latreille, P.A., 1825. Familles Naturelles du Regne Animal, Exposees Succinctement et dans un Ordre Analytique, avec l'Indication de leurs Genres. J.-B. Bailliere, Paris. 570 p.

Lawrence, J.F., 1991. Endomychidae (Cucujoidea)(including Merophysiidae, Mycetaeidae). pp. 482-485. In: Stehr, F.W. (Ed.), Immature Insects. Volume 2. Kendall/Hunt Publishing Company, Dubuque, IA.

Leach, W.E., 1815. Entomology. pp. 57-172. In: Brewster, D. (Ed.), Edinburgh Encyclopedia, volume 9. Edinburgh.

Lee, J.Y., 1988. Colored Korean Mushrooms (I). Academy Publishing, Seoul.

Leschen, R.A.B. and Carlton, C.E., 1988. Immature stages of Endomychus biguttatus Say (Coleoptera: Endomychidae) with observations on the alimentary canal. J. Kan. Entomol. Soc., 61: 321-327.

Lewis, G., 1893. A list of Coleoptera new to the fauna of Japan, with notices of unrecorded synonyms. Ent., 26: 150-153.

Mader, L., 1936. Neue Coleopteren und Notizen. Ent. Rund., 54: 97-101.

Mader, L., 1941. Eine neue Endomychide aus Japan. Ent. Blät., 37: 170.

Mulsant, E., 1846. Histoire Naturelle des Coléoptères de France. Sulcicolles-Securipalpes. Maison, Paris. xxiv +280p., 1 pl. p.

Newman, E., 1834. Attempted division of British insects into natural orders. Ent, Mag., 2: 379-431.

Ohta, Y., 1931. Beiträge zur kenntnis der Endomychiden Japans. Jour. Fac. Agr., Kok. Imp. Uni., 30: 205-244.

Panzer, G.W.F., 1795. Entomologia Germanica Exhibens Insecta per Germaniam indigena, Secundum Classes, Ordines, Genera, Species, Adiectis, Synonymis, Locis, Observationibus. I. Eleuterata. Cum Tabulis Aeneis. Deutschlands Insectenfaune oder Entomologisches Taschenbuch für das Jahr 1975. Apud Fulseckeri Haeredes, Norimbergae. 372 p.

Pic, M., 1922. Diagnoses de Coléoptères africains des recoltes de $M$. Guy Babault. Bul. Soc. Ent. Fran., 27: 238-239.

Pic, M., 1929. Nouveautés diverses. Mél. Exo.-Ent., 54: 1-36.

Pic, M., 1945. Coléoptères du globe (suite). L'Échange, Rev. Lin., 61: 10-16.

Redtenbacher, L., 1844. Tentamen dispositionis generum et specierum coleopterorum pseudotrimerorum Archiducatus Austriae. Zeit. Ent., 5: 113-132.
Reitter, E., 1887. Neue Coleopteren aus Europa, den angrenzenden Ländern und Sibirien, mit Bemerkungen über bekannte Arten. Vierter Theil. Deut. Ento. Zeit., 31: 497-528.

Rücker, H.W., Löbl, I., Tomaszewska, K.W., 2007. Family Endomychidae Leach, 1815. pp. 557-568 In: Löbl, I. \& A. Semetana (Eds.), Catalogue of Palaearctic Coleoptera. Vol. 4. Elateroidea - Derodontoidea - Bostrichoidea Lymexyloidea Cleroidea - Cucujoidea. Apollo Books, Stenstrup, Denmark.

Sasaji, H., 1978. Notes on the Japanese Endomychidae, with an establishment of a new subfamily (Coleoptera). Mem. Fac. Edu. Fuk. Uni. Ser. II (Natural Science), 28: 1-31.

Shockley, F.W., Tomaszewska, K.W. Mchugh, J.V., 2009. An annotated checklist of the handsome fungus beetles of the world (Coleoptera: Cucujoidea: Endomychidae). Zoo., 1999: 1-113.

Skelley, P.E. and Leschen, R.A.B., 2002. Chapter 92. Endomychidae Leach 1815. pp. 366-370. In: Arnett, R.H., Thomas, M.C., Skelley, P.E. and Frank, J.H. (Eds), American Beetles. CRC Press, Boca Raton, FL.

Stephens, J.F., 1831. Illustrations of British entomology or, a synopsis of indigenous insects: containing their generic and specific distinctions; with an account of their metamorphoses, times of appearance, localities, food, and economy, as far as practicable. Mandibulata. Volume IV. Baldwin and Cradock, London. $366 \mathrm{p}$.

Strohecker, H.F., 1964. A synopsis of the Amphisternini (Coleoptera: Endomychidae). Pac. Ins., 6: 319-357.

Strohecker, H.F., 1972. The genus Ancylopus in Asia and Europe (Coleoptera: Endomychidae). Pacific Insects, 14: 703-708.

Thomson, C.G., 1863. Skandinaviens Coleoptera, synoptiskt bearbetade. Vol. 5. Tryckt uti Berlingska Boktryckeriet, Lund. 40 p.

Tomaszewska, K.W., 2000. Morphology, phylogeny and classification of adult Endomychidae (Coleoptera: Cucujoidea). Ann. Zoo. (Warszawa), 50: 449-558.

Tomaszewska, K.W., 2005. Phylogeny and generic classification of the subfamily Lycoperdininae with a re-analysis of the family Endomychidae (Coleoptera, Cucujoidea). Ann. Zoo., 55(suppl. 1): $1-172$

Verhoeff, C., 1895. Vergleichend-morphologische Untersuchungen über das Abdomen der Endomychiden, Erotyliden und Languriiden (im alten Sinne) und über die Muskulatur des copulations apparates von Triplax. Arc. Nat., 61: 213-287.

Weber, F., 1801. Observationes Entomologicae, continents novorum quae condidit generum characters, et nuper detectarum specierum descriptions. Bibliopolii Academici Novi, Kiliae. 116 p. 